\title{
FETAL ADIPOSITY AND LABOR DYSTOCIA: A CASE-CONTROL STUDY
}

\author{
Mustafa Burak Akselim ${ }^{1}$, Süleyman Serkan Karaşin ${ }^{1}$, Yasin Altekin ${ }^{1}$, and Zeynep Toksoy \\ $\operatorname{Karaşin}^{1}$ \\ ${ }^{1}$ Bursa Yüksek İhtisas Eğitim ve Araştırma Hastanesi
}

September 21, 2020

\begin{abstract}
OBJECTIVE: To investigate whether increased fetal adiposity diagnosed ultrasonographically is associated with labor dystocia, increased risk of operative delivery, and shoulder dystocia. DESIGN: Prospective case-control study. SETTING: Education and research hospital. POPULATION: 400 pregnant women between 37 and 41 weeks of gestation. METHODS: Correlation analyses, logistic regression analyses, and ROC analyses to evaluate soft tissue thickness in relation to labor dystocia, shoulder dystocia, and operative delivery. MAIN OUTCOME MEASURES: In addition to standard ultrasonographic measurements, we evaluated fetal soft tissue thickness in pregnant women who started labor. RESULTS: While the vaginal delivery rate was $77.3 \%$, a cesarean was performed in $22.7 \%$ of pregnant women. We found positively correlated with the duration of the active phase and second stage of labor, birth weight of baby, and biometrical parameters. In addition, we examined and determined that the cesarean section, shoulder dystocia, and labor dystocia increased as the baby adipose tissue thickness increased. We investigated the effect of parameters on the results of the study with logistic regression analysis and possible threshold values with ROC analysis. CONCLUSION: In our study, evaluation of the fetal adipose tissue complex during delivery was significant in terms of labor dystocia and operative delivery. We think it may be a guide for future studies in the literature. Funding: This study was funded by AUTHORS Keywords: Labor, Labor dystocia, Fetal adipose tissue, Antepartum ultrasonography Tweetable Abstract: Fetal adipose tissue ultrasonographic measurement to be checked just before delivery may give clues about the progress of labor.
\end{abstract}

\section{INTRODUCTION}

Labor is a continuous, multifaceted process divided into three stages. ${ }^{1}$ The first stage refers to the time from the beginning of labor until the cervix is fully dilated. ${ }^{123}$ The second stage describes the time from full cervical dilation to delivery of the baby. ${ }^{1456}$ The time from the expulsion of the baby to the removal of the placenta refers to the third stage. ${ }^{17}$

The first stage consists of two parts, latent and active. According to current studies, the latent phase defines as 0 to $6 \mathrm{~cm}$, and however, the active phase means the duration between $6 \mathrm{~cm}$ and full cervical dilation. ${ }^{138910}$

Based on formal Friedman's study, the latent phase duration in nulliparas must be shorter than 20 hours and in multiparas, faster than 14 hours after the onset of the latent phase. ${ }^{811}$ The active phase (time from 6 to $10 \mathrm{~cm}$ ) is more rapid than the latent phase in both induced and spontaneous labors. ${ }^{1213}$ Active phase protraction means cervical dilatation in women with [?]6 $\mathrm{cm}$ and dilatation duration of less than about 1 to $2 \mathrm{~cm} /$ hour. ${ }^{10}$ Active phase arrest defines that in a pregnant woman with a cervical dilatation of [?]6 $\mathrm{cm}$ and ruptured membranes; no cervical changes for [?]4 hours despite adequate contractions or [?]6 hours even if contractions are inadequate. ${ }^{381014}$

The optimal duration for the second stage of labor is still controversial. Based on current data, it suggested for a nulliparous patient 3 hours and 2 hours for a multiparous woman. If regional anesthesia is performed, 
we can wait for 1 hour more. ${ }^{181415}$ Longer times may be defined as second stage arrest.

The protraction or arrest in the first or second stage of labor is a significant risk factor for the primary cesarean. Maternal obesity, macrosomia, cephalopelvic disproportion, neuraxial anesthesia, occiput posterior position, nulliparity, uterine abnormality, short stature (less than $150 \mathrm{~cm}$ ), maternal age, post-term pregnancy, and hypocontractile uterine activity states are associated with prolongation and arrest of birth. ${ }^{1617}$

In the first stage of labor, especially in the active phase, oxytocin augmentation and amniotomy may be an option for labor progression. ${ }^{18}$ But women with labor arrest in the first stage should be managed by cesarean delivery. ${ }^{15}$ When the second stage arrest diagnosed, the obstetrician should consider the options including observation, operative vaginal delivery, and cesarean delivery if the maternal and fetal conditions permit. ${ }^{16}$

Prolonged delivery may cause some maternal and fetal complications. In the literature, the studies show that a longer duration of the active phase and second stage of labor may be associated with risk of operative vaginal delivery, cesarean delivery, perineal lacerations, postpartum hemorrhage, chorioamnionitis, shoulder dystocia, increased risks for neonatal intensive care unit requirement, Apgar score decrease, hypoxic-ischemic encephalopathy and fetal mortality. ${ }^{151619202122232425}$

Fetal soft tissue composite is in relation with gestational diabetes, macrosomia, the risk for cesarean delivery and neonatal adiposity. ${ }^{2627282930}$

Shoulder dystocia is one of the serious obstetrical complications as it can cause permanent plexus brachialis injury. It occurs in 0.2 percent of births. Although there are several known risk factors, the clinicians often can not predict the shoulder dystocia. Clinicians should consider the risk factors for shoulder dystocia and should be prepared to address this complication in all deliveries. ${ }^{31}$ Shoulder dystocia is a subjective clinical diagnosis, but there are some studies as more objective definition criteria in the literature. ${ }^{3233}$

We have mentioned above the risk factors in prolonging labor. In this study, we will examine the relationship between fetal adipose tissue thickness without these risk factors but associated with them, prolongation of delivery and complications caused by this. In this context, it may be the first study in the literature regarding the relationship between fetal adipose tissue thickness, prolonged delivery, shoulder dystocia, and cesarean delivery.

\section{MATERIALS AND METHODS}

This article is about a prospective analysis, studied with 400 pregnant women during labor between 37 and 41 weeks, and vertex presentation. We performed this study, approved by the local ethics committee numbered 2011-KAEK-25 2019/07-17, at the Department of Obstetrics and Gynecology of the Bursa Yüksek İhtisas Education and Research Hospital, Bursa, Turkey. All participants had a confirmed estimated date of birth by first-trimester ultrasound, which correlated with their menstrual dates.

We considered two criteria accepted by the American College of Obstetricians and Gynaecologists (ACOG) and Royal College of Obstetricians and Gynaecologists (RCOG) for shoulder dystocia: 1- Failure of shoulder delivery after downward traction, 2- Deliveries requiring maneuvers in addition to gentle downward traction on the fetal head to effect delivery.

Nonvertex presentation, preterm labor, cesarean delivery history, multiple gestations, before oxytocin initiation, a nonreassuring fetal heart rate tracing, or chorioamnionitis, ablatio placenta were not included in this study population.

Macrosomia of fetus (>4500 gram), women with gestational diabetes, women of short stature (less than 150 $\mathrm{cm}$ ), occiput posterior fetal position, and history of dystocia, which are risk factors for the conditions we mentioned, were also excluded from the study.

The digital cervical examination performed in the first stage, two-four hours intervals, and one-two hours in the second stage. The results were documented according to the hours and on a partogram in addition to these records. The time from $6 \mathrm{~cm}$ to $10 \mathrm{~cm}$ and the time from complete cervical dilation to fetal head's 
expulsion recorded. Also, whether shoulder dystocia developed at each delivery and the type of birth was registered.

During labor, in the protracted active phase, we administered oxytocin if not already started. However, women with labor arrest in the active phase and the second stage had gone cesarean delivery. Otherwise, the cesarean decision was made in cases with acute fetal distress during follow-up.

Participants had an ultrasound examination before $6 \mathrm{~cm}$ cervical dilation. Standard fetal biometry was measured, including biparietal diameter (BPD), head circumference (HC), abdominal circumference (AC), and femur length (FL), yielding a calculated estimated fetal weight (EFW) using the Hadlock formula. ${ }^{34}$ Fetal adipose tissue components consisted of the anterior abdominal wall (AAW), thigh (femur)(FWT), and upper arm (humerus) (HWT) adipose tissue. We defined the fetal adipose tissue composite as total adipose tissue (TATT). Total adipose tissue components consisted of the sum of the anterior abdominal wall, thigh, and arm adipose tissue thickness.

Fetal AAW measurement obtained at the abdominal circumference view, a plane where the junction of the right and left fetal portal vein and stomach seen. The image included fetal skin and subcutaneous tissue (Figure-1). Calipers were at the echogenic area between the outer skin edge and inner margin of the anterior abdominal wall. We calculated the anterior abdominal wall thickness (AAWT) as the thickness of this echogenic rim was measured at a point nearly $2 \mathrm{~cm}$ lateral to the umbilical cord insertion. Three measurements were obtained, and the mean value was recorded.

We obtained a standard image of the FL and HL, measuring fetal thigh and arm adiposity. The calipers placed between the bones' outer face and the skin's outer face in the midline. Then, another measurement was taken from the bones' outer edge to the inner fat surface, and the fetal adiposity was calculated by subtracting this from the first measurement (Figure-2)(Figure-3). Standard perinatal and obstetric data documented during the birth.

The study's primary outcome was to investigate if fetal adiposity was associated with an increased risk of labor protraction or arrest. Secondary outcomes included the effects of fetal adiposity on an increased risk of unplanned intrapartum cesarean delivery, active phase, second stage durations, birth weight of baby, fetus's biometrical parameters, and shoulder dystocia.

\section{Statistical analysis}

For proper statistical analyses, a Windows-based SPSS 24.0 statistical analysis program was used (SPSS Inc., USA) . We examined variables via visual (histograms, probability plots) and analytical methods (Shapiro-Wilk's and Kolmogorov-Smirnov test) to determine whether they were normally distributed or not. Variables specified as mean \pm standard deviation $(\mathrm{X} \pm \mathrm{SD})$, the mean difference between groups, $95 \%$ confidence interval $(95 \% \mathrm{CI})$, median (minimum-maximum (min-max)), $\mathrm{U}$ value, frequency $(\mathrm{n})$, and percentage (\%). Student $t$-test, Mann-Whitney U test, and Chi-square test were used to compare normally distributed, undistributed, and categorical variables. Pearson and Spearman's tests were conducted to show relationships between normally and non-normally distributed and/or ordinal variables. The level of significance was as $\mathrm{p}[?] 0.05$. For the multivariate analysis, the possible factors identified with previous analyses were further entered into the logistic regression analysis to determine independent predictors of study outcomes. HosmerLemeshow goodness of fit statistics was for evaluating model fit. A \%5 type-1 error level was accepted to infer statistical significance. The diagnostic values of AAWT, HWT, FWT, and TATT measures in predicting labor prolongation, arrest, and cesarean delivery were examined by ROC curve analysis. When a significant cut-off value was observed, the sensitivity, specificity, positive and negative predictive values were presented. While evaluating the area under the curve, a \%5 type- 1 error level was used to accept a statistically significant test variable's predictive value.

\section{RESULTS}

Demographic and clinical characteristics, as well as descriptive analyses, were represented in Table-1. A total of 400 women were studied; 309 (\%77.3) delivered vaginally, and 91 (\%22.7) by cesarean section. The mean 
age of the participants was 27. The mean of the birth weight of babies was 3239.77 grams (SD: +-359.07$)$.

Before the end of the active phase and end of the second stage, the cesarean section performed in $82(20.5 \%)$ and $91(2.3 \%)$ pregnant women, respectively. However, out of 400 pregnant women, 45 were not analyzed in terms of labor protraction or arrest diagnoses in the present study because of the cesarean section was performed.

\section{Correlations among outcomes and baby adipose tissue components}

As shown in Table-2, regardless of the number of births of the participants, both soft tissue thickness of the anterior abdominal wall and total adipose tissue had significantly and positively correlated with the type of delivery, active phase, and second stage duration, birth weight of baby, biparietal diameter, abdominal circumference, femur length, shoulder dystocia, labor protraction and labor arrest $(\mathrm{p}<0.05)$.

Soft tissue thickness of thigh and arm was significantly and positively correlated with the type of delivery, active phase duration, birth weight of baby, biparietal diameter, abdominal circumference, femur length, shoulder dystocia, labor protraction, and labor arrest $(\mathrm{p}<0.05)$ (Table-2).

Participants were divided into two groups as nulliparous and parous. Binominal logistic regression was used to determine the variables that may predict labor prolongation, and labor arrest risk. According to this analysis, while the increase in fetal abdominal adipose thickness causes prolongation and arrest in labor. In the binary logistic regression analysis, we performed, each $1 \mathrm{~mm}$ increase in the anterior abdominal wall adipose tissue causes prolonged labor in nulliparous groups 3.3 times and 5.8 times in multiparous groups. Each $1 \mathrm{~mm}$ increase in total adipose tissue components causes prolonged labor in nulliparous groups 2.4 times and multiparous groups 2.9 times. Every $1 \mathrm{~mm}$ increase in the total amount of adipose tissue thickness causes the arrest of labor in the nulliparous group 1.6 times; in the parous group, it increases 1.4 times (Table-3).

In the evaluation made with ROC analysis, we found that fetal adipose tissue measurements in nulliparous and parous pregnant women had a diagnostic value in predicting the prolongation, arrest of labor, and cesarean section separately and in total. The recommended cut-off values are shown in Table- 4 . According to this analysis, the presence of total adipose tissue components of $21 \mathrm{~mm}$ and above in nulliparous women may cause arrest in labor with $92 \%$ sensitivity and $74.1 \%$ specificity. In the prediction of cesarean delivery in nulliparous women, we found this cut off value to be $19.7 \mathrm{~mm}$, with $76.9 \%$ sensitivity and $67.9 \%$ specificity. We concluded that total adipose tissue components over $21.5 \mathrm{~mm}$ in women parous group caused labor arrest with $92 \%$ sensitivity and $78.7 \%$ specificity. We indicated the complete analysis in Table- 4 .

\section{DISCUSSION}

According to the World Health Organization, birth occurs spontaneously, between 37 and 42 weeks of pregnancy in the vertex position and without significant risks throughout labor progression. ${ }^{35}$ Labor characterized by regular uterine contractions results in progressive fetal descent, expulsion, and live birth. Labor abnormalities are categorized as labor prolongation, labor protraction, or labor arrest.

Dysfunctional labor, labor dystocia, protraction/arrest disorders are quite common among women during labor, and almost 20 percent of all labors result in live births. ${ }^{36}$ Labor progress disorders are the most common reason for primary intrapartum cesarean delivery.

Labor protraction and arrest situations are in relation to many different risk factors. In 2004, Algovik $\mathrm{M}$ et al. has declared that genetic predisposition about labor prolongation. ${ }^{37}$ In another study, in 2012, the effect of pelvic floor muscle strength on labor was investigated. Pelvic floor muscles were found more substantial in the failed labor than normally progressive labor. ${ }^{38}$ Maternal age is a risk factor for cesarean section depending on prolonging labor. ${ }^{39}$ Maternal body mass index and obesity was defined as a risk factor for labor prolongation in another article. ${ }^{40}$ As emphasized in some publications in the literature, the duration of the first and second stages of labor was prolonged by the use of epidural analgesia. ${ }^{4142}$

The present study's primary purpose was to determine the effect of fetal adipose tissue components on labor progression by excluding other risk factors that cause prolongation. We planned to see the effect of fetus soft 
tissue components on the diagnosis of labor protraction or arrest. In this context, in our study, the adipose tissue components individually and as a total composite caused an extension in the active phase and the second stage of labor.

Shoulder dystocia is rarely seen, with an incidence of $0.2 \%$ to $3.0 \%$ of all vaginal deliveries. This wide range is associated with the clinician's definition of shoulder dystocia, differences in defining the degree of reporting, and the study population. ${ }^{43}$ Shoulder dystocia has been seen more frequently in pregnant women who have delivered vaginally and have longer durations of labor. ${ }^{4445}$ In a study published in 1998 and with 722 participants, it was recognized $\% 24$ shoulder dystocia. ${ }^{33}$ In another article, the shoulder dystocia rate detected 16 percent. ${ }^{32}$ In our study, we detected $\% 3.3$ of shoulder dystocia in all deliveries. These shoulder dystocias were mild, easily reduced, responded promptly to McRoberts's maneuvers alone, or combined with suprapubic pressure and did not result in neonatal injury. Longer duration of labor has associated with increased rates of cesarean delivery in the literature. ${ }^{4647}$

In a study performed with 4126 women in the second stage of labor, it was a higher duration of the second stage of labor was associated with uterine atony. ${ }^{48}$ According to another study, perineal trauma, instrumental delivery, postpartum hemorrhage, and chorioamnionitis may be higher in pregnant women who have prolonged labor. ${ }^{17}$

As seen from the studies mentioned above, prolongation of labor presents many fetal and maternal problems. The prediction of labor protraction or arrest can be vital because it is necessary to determine new diagnosis or screening methods. As in our study, the measurement of fetal fat tissue components can be a supportive method in this regard.

Farah et al. studied ultrasonographic soft tissue measurements in detecting fetal macrosomia, gestational diabetes, and growth restriction of the fetus. ${ }^{49}$ Sood AK et al. found a significant correlation between humerus soft tissue and fetal weight. ${ }^{50}$ In another study detected that fetus soft tissue measurement might help to investigate fetal macrosomia. ${ }^{51}$ In 2003, a study showing the relationship between fetus adipose tissue components and gestational diabetes had published. According to this study mentioned, values of fetus midarm, mid-thigh, subscapular and anterior abdominal fat mass were more significant in the gestational diabetes pregnancies than normal pregnant women. ${ }^{52}$

Higgins MF et al. studied with 335 diabetic pregnancy and found that anterior abdominal wall thickness measure significantly correlated with macrosomia in gestational diabetes mellitus. ${ }^{53}$ In another study ,midthigh soft tissue thickness was measured and found significantly correlated with abdominal circumference and baby birth weight. ${ }^{54}$

Our study aimed to show the relationship of measurement of fetal soft tissue components with active phase and second stage of labor duration, risk of cesarean section, shoulder dystocia, birth weight, and fetal biometric parameters. As shown, Table-2 fetus soft tissue components, both individually and in total, are significantly and positively correlated active phase and second stage duration, birth weight of baby, risk of cesarean delivery, biparietal diameter, abdominal circumference, femur length, and shoulder dystocia.

With the binary logistic regression analysis, we performed, we found that fetal fat tissue components caused prolongation or arrest in labor (Table-3). At the same time, these components increase the rate of cesarean delivery.

Also, we determined cut-off values for each of these components by performing roc analysis. In general, areas under the process characteristic curve found high values and $\mathrm{p}$ values to be significant. In cases where total adipose tissue components exceed 20-21 mm levels, labor prolonged with high sensitivity and specificity, and the cesarean delivery rate increased. In general, the adiposity of the anterior abdominal wall tissue above $8.6 \mathrm{~mm}-9.0 \mathrm{~mm}$ increases labor arrest and the going to the cesarean section (Table-4).

The results of this study show us that it may be a useful method to measure fetus adipose tissue components for an ideal follow-up of labor. Measuring these components can be considered in predicting the prolongation of labor and problems that may develop accordingly. However, it can give an idea of the measurement of 
fetal adipose tissue components in terms of risk of going to the cesarean section and shoulder dystocia during delivery.

Researches related to this problem are essential since prolonged labor, as we mentioned above, may cause many neonatal and maternal problems.

A potential limitation of this study is about long-term follow-up. Our study designed not to accurately reflect differences in clinical outcomes such as Erb's palsy at vaginal delivery or neonatal term follow-up of babies. In some morbidities, infants with increased adipose deposition may be at risk of suffering; however, given their infrequent occurrence appreciating a significant difference would require a much larger cohort.

Measurement of fetal fat tissue components is not a part of routine biometric measurements. Our study could not evaluate and analyze the relationship between adipose tissue components and biometric parameters in detail. Perhaps these adipose tissue components prolong the labor process or increase the cesarean section's risk, as they affect biometric parameters. Some studies in the literature indicate that these components are associated with gestational diabetes and macrosomia. More and more long-term studies are needed for this analysis.

In conclusion, our study determined that labor progress is longer with increased adipose deposition of the fetus. Fetus soft tissue thickness positively correlated with labor protraction and labor arrest. Measurement of soft tissue components may help provide labor follow-up. Our study showed that fetuses with increased adipose deposition were more likely to require a cesarean delivery, shoulder dystocia, and higher birth weight. Increased fetal adiposity may be predictive of the need for unplanned cesarean delivery, estimating fetal weight, and birth complications. It was perhaps the first study in the literature in terms of the analysis of fetal adipose tissue components with the progression of labor. The relationship of the parameters with the results of the study was generally found to be highly significant, but these data should be supported by more detailed studies with more patients.

Disclosure of interest

Author Akselim declares that he has no financial, personal, political, intellectual, or religious conflict of interest.

Author Karaşin declares that he has no financial, personal, political, intellectual, or religious conflict of interest.

Author Altekin declares that he has no financial, personal, political, intellectual, or religious conflict of interest.

Author Toksoy Karaşin declares that she has no financial, personal, political, intellectual, or religious conflict of interest.

Contribution to authorship

Author AKSELIM B. presented the idea, KARAŞIN SS developed the theory. ALTEKIN Y and TOKSOY KARAŞIN Z performed the measurements, performed the analysis, and drafted the manuscript. AKSELIM B. wrote the manuscript with support from KARAŞIN SS. Author KARAŞIN SS. performed the computations and checked statistical analyses. All authors discussed the results and commented on the manuscript.

Details of ethics approval

This study approved by the local ethics committee numbered 2011-KAEK-25 2019/07-17, at the Department of Obstetrics and Gynecology of the Bursa Yüksek İhtisas Education and Research Hospital, Bursa, Turkey.

Funding

This study was funded by all AUTHORS.

\section{REFERENCES}


1. Liao JB, Buhimschi CS, Norwitz ER. Normal labor: mechanism and duration. Obstet Gynecol Clin North Am . 2005;32(2):145-164, vii. doi: 10.1016/j.ogc.2005.01.001

2. FRIEDMAN E. The graphic analysis of labor. Am J Obstet Gynecol . 1954;68(6):1568-1575. doi:10.1016/0002-9378(54)90311-7

3. Rhoades JS, Cahill AG. Defining and Managing Normal and Abnormal First Stage of Labor. Obstet Gynecol Clin North Am . 2017;44(4):535-545. doi: 10.1016/j.ogc.2017.07.001

4. Lipschuetz M, Guedalia J, Cohen SM, et al. Unplanned Cesarean Delivery in the Second Stage of Labor Holds Higher Odds of Complications than in the First Stage, while Similar in Primiparas and Multiparas.Fetal Diagn Ther . January 2020:1-7. doi:10.1159/000504573

5. Hofmeyr GJ, Vogel JP, Cuthbert A, Singata M. Fundal pressure during the second stage of labour. Cochrane database Syst Rev . 2017;3(3):CD006067. doi: 10.1002/14651858.CD006067.pub3

6. Ray C Le, Fraser W, Rozenberg P, Langer B, Subtil D, Goffinet F. Duration of passive and active phases of the second stage of labour and risk of severe postpartum haemorrhage in low-risk nulliparous women.Eur J Obstet Gynecol Reprod Biol . 2011;158(2):167-172. doi: https://doi.org/10.1016/j.ejogrb.2011.04.035

7. Maged AM, Waly M, Fahmy RM, et al. Carbetocin versus rectal misoprostol for management of third stage of labor among women with low risk of postpartum hemorrhage. Int J Gynaecol Obstet . 2020;148(2):238242. doi:10.1002/ijgo.13056

8. Caughey AB, Cahill AG, Guise J-M, Rouse DJ. Safe prevention of the primary cesarean delivery. Am $J$ Obstet Gynecol . 2014;210(3):179-193. doi: https://doi.org/10.1016/j.ajog.2014.01.026

9. Lipschuetz M, Nir EA, Cohen SM, et al. Cervical dilation at the time of epidural catheter insertion is not associated with the degree of prolongation of the first or second stages of labor, or the rate of instrumental vaginal delivery. Acta Obstet Gynecol Scand . February 2020. doi:10.1111/aogs.13822

10. Zhang J, Troendle J, Mikolajczyk R, Sundaram R, Beaver J, Fraser W. The natural history of the normal first stage of labor. Obstet Gynecol . 2010;115(4):705-710. doi:10.1097/AOG.0b013e3181d55925

11. FRIEDMAN EA, NISWANDER KR, SACHTLEBEN MR, NEMORE J. Dysfunctional Labor: VIII. Relative Accuracy of Clinical and Graphic Diagnostic Methods. Obstet Gynecol . 1969;33(2). https://journals.lww.com/greenjournal/Fulltext/1969/02000/Dysfunctional_Labor__VIII__Relative_Accuracy_of.1.aspx.

12. Harper LM, Caughey AB, Odibo AO, Roehl KA, Zhao Q, Cahill AG. Normal progress of induced labor. Obstet Gynecol . 2012;119(6):1113-1118. doi:10.1097/AOG.0b013e318253d7aa

13. Becker DA, Szychowski JM, Kuper SG, Jauk VC, Wang MJ, Harper LM. Labor Curve Analysis of Medically Indicated Early Preterm Induction of Labor. Obstet Gynecol . 2019;134(4):759-764. doi:10.1097/AOG.0000000000003467

14. Spong CY, Berghella V, Wenstrom KD, Mercer BM, Saade GR. Preventing the first cesarean delivery: summary of a joint Eunice Kennedy Shriver National Institute of Child Health and Human Development, Society for Maternal-Fetal Medicine, and American College of Obstetricians and Gynecologists Workshop. Obstet Gynecol . 2012;120(5):1181-1193. doi:10.1097/aog.0b013e3182704880

15. Obstetric care consensus no. 1: safe prevention of the primary cesarean delivery. Obstet Gynecol . 2014;123(3):693-711. doi: 10.1097/01.AOG.0000444441.04111.1d

16. ACOG Practice Bulletin Number 49, December 2003: Dystocia and augmentation of labor. Obstet Gynecol . 2003;102(6):1445-1454. doi: 10.1016/j.obstetgynecol.2003.10.011

17. Myles TD, Santolaya J. Maternal and neonatal outcomes in patients with a prolonged second stage of labor. Obstet Gynecol . 2003;102(1):52-58. doi:10.1016/s0029-7844(03)00400-9 
18. Wei S, Wo BL, Qi H-P, et al. Early amniotomy and early oxytocin for prevention of, or therapy for, delay in first stage spontaneous labour compared with routine care. Cochrane database Syst Rev . 2013;(8):CD006794. doi: 10.1002/14651858.CD006794.pub4

19. Kjaergaard H, Olsen J, Ottesen B, Dykes A-K. Incidence and outcomes of dystocia in the active phase of labor in term nulliparous women with spontaneous labor onset. Acta Obstet Gynecol Scand . 2009;88(4):402407. doi:10.1080/00016340902811001

20. Leveno KJ, Nelson DB, McIntire DD. Second-stage labor: how long is too long? Am J Obstet Gynecol . 2016;214(4):484-489. doi: 10.1016/j.ajog.2015.10.926

21. Govindappagari S, Greene N, Burwick R, Wong MS, Gregory KD. Maternal and Neonatal Morbidity After 4 and 6 Hours of Protracted Active Labor in Nulliparous Term Pregnancies. Obstet Gynecol . 2020;135(1):185-193. doi:10.1097/AOG.0000000000003587

22. Allen VM, Baskett TF, O'Connell CM, McKeen D, Allen AC. Maternal and perinatal outcomes with increasing duration of the second stage of labor. Obstet Gynecol . 2009;113(6):1248-1258. doi:10.1097/AOG.0b013e3181a722d6

23. Laughon SK, Berghella V, Reddy UM, Sundaram R, Lu Z, Hoffman MK. Neonatal and maternal outcomes with prolonged second stage of labor.Obstet Gynecol . 2014;124(1):57-67. doi:10.1097/AOG.0000000000000278

24. Cheng YW, Shaffer BL, Bryant AS, Caughey AB. Length of the first stage of labor and associated perinatal outcomes in nulliparous women.Obstet Gynecol . 2010;116(5):1127-1135. doi: 10.1097/AOG.0b013e3181f5eaf0

25. Stephansson O, Sandstrom A, Petersson G, Wikstrom A-K, Cnattingius S. Prolonged second stage of labour, maternal infectious disease, urinary retention and other complications in the early postpartum period. BJOG . 2016;123(4):608-616. doi:10.1111/1471-0528.13287

26. Hehir MP, Burke N, Burke G, et al. Sonographic markers of fetal adiposity and risk of Cesarean delivery. Ultrasound Obstet Gynecol . 2019;54(3):338-343. doi:10.1002/uog.20263

27. Jarvie EM, Stewart FM, Ramsay JE, et al. Maternal Adipose Tissue Expansion, A Missing Link in the Prediction of Birth Weight Centile.J Clin Endocrinol Metab . 2020;105(3). doi:10.1210/clinem/dgz248

28. Kosus N, Kosus A. Can fetal abdominal visceral adipose tissue and subcutaneous fat thickness be used for correct estimation of fetal weight? A preliminary study. J Obstet Gynaecol . 2019;39(5):594-600. doi:10.1080/01443615.2018.1530971

29. Aksoy H, Aksoy U, Yucel B, Saygi Ozyurt S, Aydin T, Alparslan Babayigit M. Fetal anterior abdominal wall thickness may be an early ultrasonographic sign of gestational diabetes mellitus. J Matern Fetal Neonatal Med . 2016;29(12):2028-2032. doi:10.3109/14767058.2015.1072164

30. Ikenoue S, Waffarn F, Sumiyoshi K, et al. Association of ultrasound-based measures of fetal body composition with newborn adiposity. Pediatr Obes . 2017;12 Suppl 1:86-93. doi:10.1111/ijpo.12198

31. Practice Bulletin No 178: Shoulder Dystocia. Obstet Gynecol . 2017;129(5): e123-e133. doi:10.1097/AOG.0000000000002043

32. Spong CY, Beall M, Rodrigues D, Ross MG. An objective definition of shoulder dystocia: Prolonged headto-body delivery intervals and/or the use of ancillary obstetric maneuvers. Obstet Gynecol . 1995;86(3):433436. doi:10.1016/0029-7844(95)00188-W

33. Beall MH, Spong C, McKay J, Ross MG. Objective definition of shoulder dystocia: A prospective evaluation. Am J Obstet Gynecol . 1998;179(4):934-937. doi:10.1016/S0002-9378(98)70191-7 
34. Diwakar RK. Obstetric Ultrasound. In: Diwakar RK, ed. Basics of Abdominal, Gynaecological, Obstetrics and Small Parts Ultrasound. Singapore: Springer Singapore; 2018:77-119. doi:10.1007/978-981-104873-9_4

35. Technical Working Group WHO. Care in Normal Birth: A Practical Guide. Birth . 1997;24(2):121-123. doi:10.1111/j.1523-536X.1997. 00121.pp.x

36. Zhu B-P, Grigorescu V, Le T, et al. Labor dystocia and its association with interpregnancy interval. Am J Obstet Gynecol . 2006;195(1):121-128. doi: 10.1016/j.ajog.2005.12.016

37. Algovik M, Nilsson E, Cnattingius S, Lichtenstein P, Nordenskjöld A, Westgren M. Genetic influence on dystocia. Acta Obstet Gynecol Scand . 2004;83(9):832-837. doi:10.1111/j.0001-6349.2004. 00544.x

38. Aran T, Osmanagaoglu MA, Kart C, Guven S, Sahin M, Unsal MA. Failed labor induction in nulliparous women at term: the role of pelvic floor muscle strength. Int Urogynecol J . 2012;23(8):1105-1110. doi:10.1007/s00192-012-1754-7

39. Ecker JL, Chen KT, Cohen AP, Riley LE, Lieberman ES. Increased risk of cesarean delivery with advancing maternal age: indications and associated factors in nulliparous women. Am J Obstet Gynecol . 2001;185(4):883-887. doi:10.1067/mob.2001.117364

40. Kominiarek MA, Zhang J, Vanveldhuisen P, Troendle J, Beaver J, Hibbard JU. Contemporary labor patterns: the impact of maternal body mass index. Am J Obstet Gynecol . 2011;205(3): 244.e1-8. doi: 10.1016/j.ajog.2011.06.014

41. Naito Y, Ida M, Yamamoto R, Tachibana K, Kinouchi K. The effect of labor epidural analgesia on labor, delivery, and neonatal outcomes: a propensity score-matched analysis in a single Japanese institute.JA Clin reports . 2019;5(1):40. doi:10.1186/s40981-019-0260-z

42. Anim-Somuah M, Smyth RM, Jones L. Epidural versus non-epidural or no analgesia in labour. Cochrane database Syst Rev . 2011;(12):CD000331. doi: 10.1002/14651858.CD000331.pub3

43. Gherman RB, Chauhan S, Ouzounian JG, Lerner H, Gonik B, Goodwin TM. Shoulder dystocia: the unpreventable obstetric emergency with empiric management guidelines. Am J Obstet Gynecol . 2006;195(3):657-672.

44. Mehta SH, Bujold E, Blackwell SC, Sorokin Y, Sokol RJ. Is abnormal labor associated with shoulder dystocia in nulliparous women? Am J Obstet Gynecol . 2004;190(6):1604-1609. doi: 10.1016/j.ajog.2004.03.067

45. Harper LM, Caughey AB, Roehl KA, Odibo AO, Cahill AG. Defining an abnormal first stage of labor based on maternal and neonatal outcomes.Am J Obstet Gynecol . 2014;210(6): 536.e1-7. doi: 10.1016/j.ajog.2013.12.027

46. Debby A, Rotmensch S, Girtler O, Sadan O, Golan A, Glezerman M. Clinical significance of the floating fetal head in nulliparous women in labor. $J$ Reprod Med . 2003;48(1):37-40.

47. Grobman WA, Bailit J, Lai Y, et al. Association of the Duration of Active Pushing with Obstetric Outcomes. Obstet Gynecol . 2016;127(4):667-673. doi:10.1097/AOG.0000000000001354

48. Rouse DJ, Weiner SJ, Bloom SL, et al. Second-stage labor duration in nulliparous women: relationship to maternal and perinatal outcomes.Am J Obstet Gynecol . 2009;201(4): 357.e1-7. doi: 10.1016/j.ajog.2009.08.003

49. Farah N, Stuart B, Donnelly V, Rafferty G, Turner M. What is the value of ultrasound soft tissue measurements in the prediction of abnormal fetal growth? J Obstet Gynaecol (Lahore) . 2009;29(6):457-463. doi:10.1080/01443610903003209

50. Sood AK, Yancey M, Richards D. Prediction of fetal macrosomia using humeral soft tissue thickness. Obstet Gynecol . 1995;85(6):937-940. doi: https://doi.org/10.1016/0029-7844(95)00081-2 
51. Maruotti GM, Saccone G, Martinelli P. Third trimester ultrasound soft-tissue measurements accurately predict macrosomia. J Matern Neonatal Med . 2017;30(8):972-976. doi:10.1080/14767058.2016.1193144

52. Larciprete G, Valensise H, Vasapollo B, et al. Fetal subcutaneous tissue thickness (SCTT) in healthy and gestational diabetic pregnancies. Ultrasound Obstet Gynecol Off J Int Soc Ultrasound Obstet Gynecol . 2003;22(6):591-597. doi:10.1002/uog.926

53. Higgins MF, Russell NM, Mulcahy CH, Coffey M, Foley ME, McAuliffe FM. Fetal anterior abdominal wall thickness in diabetic pregnancy.Eur J Obstet Gynecol Reprod Biol . 2008;140(1):43-47. doi: https://doi.org/10.1016/j.ejogrb.2008.02.021

54. Scioscia M, Scioscia F, Vimercati A, et al. Estimation of fetal weight by measurement of fetal thigh soft-tissue thickness in the late third trimester. Ultrasound Obstet Gynecol . 2008;31(3):314-320. doi:10.1002/uog.5253

\section{TABLES}

Table 1: Descriptive analyses of values regarding the mothers and the babies

\begin{tabular}{ll}
\hline & Pregnant women (n=400) \\
\hline Characteristics of Mothers & $\mathbf{X} \pm \mathbf{S D} /$ Median (min-max) \\
Age (year) (n; \%) & $27(18-44)$ \\
Nulliparous (n) & $186 ; 46.5 \%$ \\
Parous (n; \%) & $214 ; 53.5 \%$ \\
Vaginal delivery (n; \%) & $309 ; 77.3 \%$ \\
Cesarean (n; \%) & $91 ; 22.8 \%$ \\
Active phase duration (min) (n=318) & $95(10-600)$ \\
Second stage duration (min) (n=309) & $15(5-150)$ \\
Characteristics of Babies & \\
Birth weight of the baby (gr) & $3239.77 \pm 359.07$ \\
Biparietal diameter (mm) & $90(76-98)$ \\
Abdominal circumference (mm) & $343.65 \pm 12.28$ \\
Thigh circumference (mm) & $72.50 \pm 3.33$ \\
Soft tissue thickness of the anterior & $7.89 \pm 1.65$ \\
abdominal wall (mm) & \\
Soft tissue thickness of thigh (mm) & $5.54 \pm 1.29$ \\
Soft tissue thickness of arm (mm) & $4.99 \pm 1.19$ \\
Total adipose tissue/composite (mm) & $18.42 \pm 3.35$ \\
Presence of shoulder dystocia (n; \%) & $13 ; 3.3 \%$ \\
Presence of labor protraction (n; \%) & $113 ; 28.3 \%$ \\
Presence of labor arrest in active phase (n; & $30 ; 7.5 \%$ \\
\%) & \\
Presence of labor arrest in second phase (n; & $8 ; 2 \%$ \\
\%) & \\
\hline
\end{tabular}

mm: millimeter, min: minute, gr: gram, n: frequency, \%: percentage, X: mean, SD: standard deviation, min: minimum, max: maximum. Descriptive analyses were presented using $(\mathrm{X} \pm \mathrm{SD})$, median (min-max) and $(\mathrm{n} ; \%)$ for normally distributed, non-normally distributed and categorical variables, respectively.

Table-2: Correlations among outcomes and fetus adipose tissue components 


\begin{tabular}{|c|c|c|c|c|c|c|c|c|}
\hline & $\begin{array}{l}\text { Soft } \\
\text { tissue } \\
\text { thickness } \\
\text { of the } \\
\text { anterior } \\
\text { abdomi- } \\
\text { nal wall } \\
(\mathrm{mm})\end{array}$ & $\begin{array}{l}\text { Soft } \\
\text { tissue } \\
\text { thickness } \\
\text { of the } \\
\text { anterior } \\
\text { abdomi- } \\
\text { nal wall } \\
(\mathrm{mm})\end{array}$ & $\begin{array}{l}\text { Soft } \\
\text { tissue } \\
\text { thickness } \\
\text { of thigh } \\
(\text { fe- } \\
\text { mur })(\mathrm{mm})\end{array}$ & $\begin{array}{l}\text { Soft } \\
\text { tissue } \\
\text { thickness } \\
\text { of thigh } \\
(\text { fe- } \\
\text { mur })(\mathrm{mm})\end{array}$ & $\begin{array}{l}\text { Soft } \\
\text { tissue } \\
\text { thickness } \\
\text { of arm } \\
\text { (humerus) }\end{array}$ & $\begin{array}{l}\text { Soft } \\
\text { tissue } \\
\text { thickness } \\
\text { of arm } \\
\text { m(hi)merus) }\end{array}$ & $\begin{array}{l}\text { Total } \\
\text { adipose } \\
\text { tissue } \\
\text { thickness } \\
\text { m(m)m) }\end{array}$ & $\begin{array}{l}\text { Total } \\
\text { adipos } \\
\text { tissue } \\
\text { thickn } \\
(\mathrm{mm})\end{array}$ \\
\hline & $\mathbf{r}$ & $\mathbf{p}$ & $\mathbf{r}$ & $\mathbf{p}$ & $\mathbf{r}$ & $\mathrm{p}$ & $\mathbf{r}$ & $\mathbf{p}$ \\
\hline $\begin{array}{l}\text { Age } \\
\text { (year) }\end{array}$ & 0.056 & 0.262 & 0.028 & 0.581 & 0.139 & $0.005^{\#}$ & 0.085 & 0.088 \\
\hline Nulliparous/ & /Pal33us & 0.504 & 0.010 & 0.846 & 0.077 & 0.126 & 0.010 & 0.846 \\
\hline $\begin{array}{l}\text { Type of } \\
\text { delivery } \\
\text { (Ceserean } \\
\text { increase) }\end{array}$ & 0.316 & $<\mathbf{0 . 0 0 1}^{\#}$ & 0.327 & $<\mathbf{0 . 0 0 1}^{\#}$ & 0.301 & $<\mathbf{0 . 0 0 1} \#$ & 0.384 & $<\mathbf{0 . 0 0}$ \\
\hline $\begin{array}{l}\text { Active } \\
\text { phase } \\
\text { duration } \\
(\min ) \\
(\mathrm{n}=\mathbf{3 1 8})\end{array}$ & 0.619 & $<\mathbf{0 . 0 0 1}^{\#}$ & 0.448 & $<0.001^{\#}$ & 0.430 & $<0.001 \#$ & 0.626 & $<0.00$ \\
\hline $\begin{array}{l}\text { Second } \\
\text { stage } \\
\text { duration } \\
(\min ) \\
(n=309)\end{array}$ & 0.189 & $0.001^{\#}$ & 0.102 & 0.074 & -0.009 & 0.870 & 0.129 & $0.023^{\#}$ \\
\hline $\begin{array}{l}\text { Birth } \\
\text { weight of } \\
\text { the baby } \\
\text { (gr) }\end{array}$ & 0.220 & $<0.001^{*}$ & 0.198 & $<0.001^{*}$ & 0.182 & $<0.001^{*}$ & 0.249 & $<0.00$ \\
\hline $\begin{array}{l}\text { Biparietal } \\
\text { diameter } \\
(\mathrm{mm})\end{array}$ & 0.189 & $<\mathbf{0 . 0 0 1}^{\#}$ & 0.112 & $0.025 \#$ & 0.137 & $0.006^{\#}$ & 0.188 & $<0.00$ \\
\hline $\begin{array}{l}\text { Abdominal } \\
\text { circumfer- } \\
\text { ence } \\
(\mathrm{mm})\end{array}$ & 0.278 & $<0.001 *$ & 0.193 & $<0.001^{*}$ & 0.206 & $<0.001^{*}$ & 0.283 & $<0.00$ \\
\hline $\begin{array}{l}\text { Thigh } \\
\text { circumfer- } \\
\text { ence } \\
(\mathrm{mm})\end{array}$ & 0.157 & $0.002^{*}$ & 0.105 & $0.036^{*}$ & 0.079 & 0.114 & 0.146 & $0.004^{*}$ \\
\hline $\begin{array}{l}\text { Shoulder } \\
\text { dystocia }\end{array}$ & 0.242 & $<\mathbf{0 . 0 0 1} \#$ & 0.196 & $<0.0011^{\#}$ & 0.154 & $<0.001 \#$ & 0.253 & $<0.00$ \\
\hline $\begin{array}{l}\text { Labor } \\
\text { protrac- } \\
\text { tion }\end{array}$ & 0.706 & $<\mathbf{0 . 0 0 1}^{\#}$ & 0.572 & $<\mathbf{0 . 0 0 1}^{\#}$ & 0.512 & $<\mathbf{0 . 0 0 1}^{\#}$ & 0.728 & $<0.00$ \\
\hline $\begin{array}{l}\text { Labor } \\
\text { arrest }\end{array}$ & 0.332 & $<0.0011^{\#}$ & 0.342 & $<0.001^{\#}$ & 0.328 & $<0.0011^{\#}$ & 0.391 & $<0.00$ \\
\hline
\end{tabular}

min: minute, gr: gram, mm: millimeter, $r$ : correlation coefficient value. Pearson test: $\mathrm{p}<0.05^{*}$ and Spearman 
test: $\mathrm{p}<0.05^{\#}$. 
Risk

Factors:

Labor

Nulliparous Nulliparous

Protraction

Group

Group

Nulliparous

Nulliparous

Parous

Parous

Group

Parous

Parous

Table-

3:

Binary

Logis-

tic

Re-

gres-

sion

Analy-

sis in

terms

of

Labor

Pro-

trac-

tion,

Labor

Arrest,

Ce-

serean

Deliv-

ery

and

Shoul-

der

Dysto-

cia

be-

tween

Nulli-

parous

and

Parous

Groups

Risk

Factors:

Labor

Protrac-

tion

Nulli-

parous

Group

Nulli-

parous

Group

Nulli-

parous

Group

Nulli-

parous

Group

Parous

Group

Parous

Group 
Risk

Factors:

Labor

Nulliparous Nulliparous

Protraction

Group

Group

Nulliparous

Nulliparous

Parous

Parous

Group

Group

Parous

Parous

Group

Group

Risk

Factors:

Labor

Nulliparous Nulliparous

Arrest

Group

Group

Nulliparous

Group

Nulliparous Parous

Group

Parous

Wald

Group

Parous

O.R.

C.I.

$\mathrm{p}$

0,847 -

0,129

1,093

1,814

0,129

,

Group

$\% 95$

C.I.

Abdom-

inal

Wall

Adipose

Thickness

Femur

2,684

1,539

0,919

0,101

3,966

1,799

1,009 -

0,672-

1,777

Adipose

Thickness

Humerus

10,355

2,682

2,578

0,001

2,989

1,708

, $931-$

4,891

3,133

Thickness

Total

23,661

1,605

1,327-

$<0,001$

14,877

1,942

1,495

1,219-

1,833

Tissue

Thickness 


\begin{tabular}{|c|c|c|c|c|c|c|c|c|}
\hline $\begin{array}{l}\text { Risk } \\
\text { Factors: } \\
\text { Labor } \\
\text { Arrest }\end{array}$ & $\begin{array}{l}\text { Nulliparous } \\
\text { Group }\end{array}$ & $\begin{array}{l}\text { Nulliparous } \\
\text { Group }\end{array}$ & $\begin{array}{l}\text { Nulliparous } \\
\text { Group }\end{array}$ & $\begin{array}{l}\text { Nulliparous } \\
\text { Group }\end{array}$ & $\begin{array}{l}\text { Parous } \\
\text { Group }\end{array}$ & $\begin{array}{l}\text { Parous } \\
\text { Group }\end{array}$ & $\begin{array}{l}\text { Parous } \\
\text { Group }\end{array}$ & $\begin{array}{l}\text { Parous } \\
\text { Group }\end{array}$ \\
\hline OR: & OR: & OR: & OR: & OR: & OR: & OR: & OR: & OR: \\
\hline odds & odds & odds & odds & odds & odds & odds & odds & odds \\
\hline ratio; & ratio; & ratio; & ratio; & ratio; & ratio; & ratio; & ratio; & ratio; \\
\hline CI: con- & CI: con- & CI: con- & CI: con- & CI: con- & CI: con- & CI: con- & CI: con- & CI: con \\
\hline fidence & fidence & fidence & fidence & fidence & fidence & fidence & fidence & fidence \\
\hline interval; & interval; & interval; & interval; & interval; & interval; & interval; & interval; & interv \\
\hline Wald: & Wald: & Wald: & Wald: & Wald: & Wald: & Wald: & Wald: & Wald: \\
\hline test & test & test & test & test & test & test & test & test \\
\hline statistic & statistic & statistic & statistic & statistic & statistic & statistic & statistic & statist \\
\hline value. & value. & value. & value. & value. & value. & value. & value. & value. \\
\hline Since & Since & Since & Since & Since & Since & Since & Since & Since \\
\hline the de- & the de- & the de- & the de- & the de- & the de- & the de- & the de- & the de- \\
\hline pendent & pendent & pendent & pendent & pendent & pendent & pendent & pendent & ende \\
\hline variable & variable & variable & variable & variable & variable & variable & variable & variab \\
\hline consists & consists & consists & consists & consists & consists & consists & consists & consis \\
\hline of 2 & of 2 & of 2 & of 2 & of 2 & of 2 & of 2 & of 2 & of 2 \\
\hline groups, & groups, & groups, & groups, & groups, & groups, & groups, & groups, & groups, \\
\hline binary & binary & binary & binary & binary & binary & binary & binary & binary \\
\hline logistic & logistic & logistic & logistic & logistic & logistic & logistic & logistic & logistic \\
\hline regres- & regres- & regres- & regres- & regres- & regres- & regres- & regres- & regres- \\
\hline sion & sion & sion & sion & sion & sion & sion & sion & sion \\
\hline used. & used. & used. & used. & used. & used. & used. & used. & used. \\
\hline Enter & Enter & Enter & Enter & Enter & Enter & Enter & Enter & Enter \\
\hline method & method & method & method & method & method & method & method & method \\
\hline used in & used in & used in & used in & used in & used in & used in & used in & used in \\
\hline analysis. & analysis. & analysis. & analysis. & analysis. & analysis. & analysis. & analysis. & analysis \\
\hline Hosmer & Hosmer & Hosmer & Hosmer & Hosmer & Hosmer & Hosmer & Hosmer & Hosmer \\
\hline and & and & and & and & and & and & and & and & and \\
\hline Lemeshow & Lemeshow & Lemeshow & Lemeshow & Lemeshow & Lemeshow & Lemeshow & Lemeshow & Lemesh \\
\hline test $\mathrm{p}$ & test $\mathrm{p}$ & test $\mathrm{p}$ & test $\mathrm{p}$ & test $\mathrm{p}$ & test $\mathrm{p}$ & test p & test p & test $\mathrm{p}$ \\
\hline values: & values: & values: & values: & values: & values: & values: & values: & values: \\
\hline 0.859 & 0.859 & 0.859 & 0.859 & 0.859 & 0.859 & 0.859 & 0.859, & 0.859 \\
\hline 0.845 & 0.845 & 0.845 & 0.845 & 0.845 & 0.845 & 0.845 & 0.845 & 0.845 \\
\hline (for nul- & (for nul- & (for nul- & (for nul- & (for nul- & (for nul- & (for nul- & (for nul- & (for nul \\
\hline liparous & liparous & liparous & liparous & liparous & liparous & liparous & liparous & liparous \\
\hline group & group & group & group & group & group & group & group & group \\
\hline and & and & and & and & and & and & and & and & and \\
\hline parous & parous & parous & parous & parous & parous & parous & parous & parous \\
\hline group, & group, & group, & group, & group, & group, & group, & group, & group, \\
\hline respec- & respec- & respec- & respec- & respec- & respec- & respec- & respec- & respec- \\
\hline tively) & tively) & tively) & tively) & tively) & tively) & tively) & tively) & tively) \\
\hline and the & and the & and the & and the & and the & and the & and the & and the & and the \\
\hline models & models & models & models & models & models & models & models & models \\
\hline had & had & had & had & had & had & had & had & had \\
\hline good & good & good & good & good & good & good & good & good \\
\hline data & data & data & data & data & data & data & data & data \\
\hline
\end{tabular}


Risk

Factors:

\begin{tabular}{|c|c|c|c|c|c|c|c|c|}
\hline Labor & Nulliparous & Nulliparous & Nulliparous & Nulliparous & Parous & Parous & Parous & Parous \\
\hline Arrest & Group & Group & Group & Group & Group & Group & Group & Group \\
\hline
\end{tabular}

Table-4: ROC analyse tables

\begin{tabular}{|c|c|c|c|c|c|c|c|c|}
\hline $\begin{array}{l}\text { Nulliparous } \\
\text { Labor } \\
\text { Protraction }\end{array}$ & $\begin{array}{l}\text { Nulliparous } \\
\text { Labor } \\
\text { Protraction }\end{array}$ & $\begin{array}{l}\text { Nulliparous } \\
\text { Labor } \\
\text { Protraction }\end{array}$ & $\begin{array}{l}\text { Nulliparous } \\
\text { Labor } \\
\text { Protraction }\end{array}$ & $\begin{array}{l}\text { Nulliparous } \\
\text { Labor } \\
\text { Protraction }\end{array}$ & $\begin{array}{l}\text { Nulliparous } \\
\text { Labor } \\
\text { Protraction }\end{array}$ & $\begin{array}{l}\text { Nulliparous } \\
\text { Labor } \\
\text { Protraction }\end{array}$ & $\begin{array}{l}\text { Nulliparous } \\
\text { Labor } \\
\text { Protraction }\end{array}$ & $\begin{array}{l}\text { Nullipa } \\
\text { Labor } \\
\text { Protrac }\end{array}$ \\
\hline $\mathrm{RF}$ & $\begin{array}{l}\text { AUC } \\
(\% 95)\end{array}$ & Cut off & $\mathrm{p}$ & Sens & Spes & $\mathrm{PPV}$ & NPV & PLR \\
\hline AAWT & $\begin{array}{l}0,926(0.884- \\
0,967)\end{array}$ & 8,6 & $<0.001$ & 88,1 & 85,6 & 77,6 & 92,7 & 6,1 \\
\hline HWT & $\begin{array}{l}0,847(0,788- \\
0,906)\end{array}$ & 4,6 & 0.003 & 89,8 & 63,5 & 57,4 & 92,7 & 2,4 \\
\hline FWT & $\begin{array}{l}0,873(0,819- \\
0,926)\end{array}$ & 5,3 & 0.002 & 89,8 & 73,1 & 62,7 & 93,5 & 3,3 \\
\hline TATWT & $\begin{array}{l}0,954(0,924- \\
0,984)\end{array}$ & 19,8 & $<0.001$ & 86,4 & 93,3 & 81,2 & 92 & 12,8 \\
\hline Nulliparous & Nulliparous & Nulliparous & Nulliparous & Nulliparous & Nulliparous & Nulliparous & Nulliparous & Nullipa \\
\hline Labor & Labor & Labor & Labor & Labor & Labor & Labor & Labor & Labor \\
\hline Arrest & Arrest & Arrest & Arrest & Arrest & Arrest & Arrest & Arrest & Arrest \\
\hline $\mathrm{RF}$ & $\begin{array}{l}\text { AUC } \\
(\% 95)\end{array}$ & Cut off & $\mathrm{p}$ & Sens & Spes & PPV & NPV & PLR \\
\hline AAWT & $\begin{array}{l}0,810(0,739- \\
0,880)\end{array}$ & 8,6 & $<0.001$ & 84 & 72,7 & 35,6 & 96,2 & 3 \\
\hline HWT & $\begin{array}{l}0,832(0,751- \\
0,912)\end{array}$ & 5,4 & 0.002 & 72 & 76,3 & 35,3 & 93,8 & 3 \\
\hline FWT & $\begin{array}{l}0,810(0,736- \\
0,885)\end{array}$ & 6,3 & $<0.001$ & 60 & 80 & 35,7 & 91,8 & 3 \\
\hline TATWT & $\begin{array}{l}0,863(0,804- \\
0,921)\end{array}$ & 19,9 & $<0.001$ & 92 & 74,1 & 37,9 & 97,2 & 3,5 \\
\hline Nulliparous & Nulliparous & Nulliparous & Nulliparous & Nulliparous & Nulliparous & Nulliparous & Nulliparous & Nullipa \\
\hline Ceserean & Ceserean & Ceserean & Ceserean & Ceserean & Ceserean & Ceserean & Ceserean & Ceserea \\
\hline Delivery & Delivery & Delivery & Delivery & Delivery & Delivery & Delivery & Delivery & Deliver \\
\hline $\mathrm{RF}$ & $\begin{array}{l}\text { AUC } \\
(\% 95)\end{array}$ & Cut off & $\mathrm{p}$ & Sens & Spes & PPV & NPV & PLR \\
\hline AAWT & $\begin{array}{l}0,707(0,628- \\
0,785)\end{array}$ & 8,8 & $<0.001$ & 65,4 & 67,9 & 43,4 & 82,7 & 2,04 \\
\hline HWT & $\begin{array}{l}0,726(0,646- \\
0,806)\end{array}$ & 5,6 & $<0.001$ & 50,1 & 83,6 & 54,2 & 81,2 & 3,05 \\
\hline FWT & $\begin{array}{l}0,744(0,668- \\
0,821)\end{array}$ & 5,8 & $<0.001$ & 67,3 & 67,2 & 45,3 & 83,8 & 2,05 \\
\hline TATWT & $\begin{array}{l}0,761(0,688- \\
0,834)\end{array}$ & 18,6 & 0.003 & 76,9 & 67,9 & 46,9 & 86,7 & 2,40 \\
\hline Multiparous & Multiparous & Multiparous & Multiparous & Multiparous & Multiparous & Multiparous & Multiparous & Multips \\
\hline Labor & Labor & Labor & Labor & Labor & Labor & Labor & Labor & Labor \\
\hline Protraction & Protraction & Protraction & Protraction & Protraction & Protraction & Protraction & Protraction & Protrac \\
\hline
\end{tabular}




\begin{tabular}{|c|c|c|c|c|c|c|c|c|}
\hline $\begin{array}{l}\text { Nulliparous } \\
\text { Labor } \\
\text { Protraction }\end{array}$ & $\begin{array}{l}\text { Nulliparous } \\
\text { Labor } \\
\text { Protraction }\end{array}$ & $\begin{array}{l}\text { Nulliparous } \\
\text { Labor } \\
\text { Protraction }\end{array}$ & $\begin{array}{l}\text { Nulliparous } \\
\text { Labor } \\
\text { Protraction }\end{array}$ & $\begin{array}{l}\text { Nulliparous } \\
\text { Labor } \\
\text { Protraction }\end{array}$ & $\begin{array}{l}\text { Nulliparous } \\
\text { Labor } \\
\text { Protraction }\end{array}$ & $\begin{array}{l}\text { Nulliparous } \\
\text { Labor } \\
\text { Protraction }\end{array}$ & $\begin{array}{l}\text { Nulliparous } \\
\text { Labor } \\
\text { Protraction }\end{array}$ & $\begin{array}{l}\text { Nullipa } \\
\text { Labor } \\
\text { Protrac }\end{array}$ \\
\hline$\overline{\mathrm{RF}}$ & $\begin{array}{l}\text { AUC } \\
(\% 95)\end{array}$ & Cut off & $\mathrm{p}$ & Sens & Spes & $\mathrm{PPV}$ & NPV & PLR \\
\hline AAWT & $\begin{array}{l}0,947(0,915- \\
0,980)\end{array}$ & 8,6 & $<0.001$ & $94,4 \%$ & $90,6 \%$ & 88,9 & 78,2 & 10,0 \\
\hline HWT & $\begin{array}{l}0,801(0,731- \\
0,870)\end{array}$ & 5,4 & 0.004 & $72,2 \%$ & $76,8 \%$ & 76,9 & 75,4 & 3,1 \\
\hline FWT & $\begin{array}{l}0,840(0,780- \\
0,900)\end{array}$ & 6,2 & $<0.001$ & $68,5 \%$ & $86,2 \%$ & 70,4 & 78,8 & 5,0 \\
\hline TATWT & $\begin{array}{l}0,953(0,918- \\
0,988)\end{array}$ & 19,9 & $<0.001$ & $92,6 \%$ & $93,5 \%$ & 93,3 & 84,5 & 14,2 \\
\hline Multiparous & Multiparous & Multiparous & Multiparous & Multiparous & Multiparous & Multiparous & Multiparous & Multips \\
\hline Labor & Labor & Labor & Labor & Labor & Labor & Labor & Labor & Labor \\
\hline Arrest & Arrest & Arrest & Arrest & Arrest & Arrest & Arrest & Arrest & Arrest \\
\hline $\mathrm{RF}$ & $\begin{array}{l}\text { AUC } \\
(\% 95)\end{array}$ & Cut off & $\mathrm{p}$ & Sens & Spes & PPV & NPV & PLR \\
\hline AAWT & $\begin{array}{l}0,795(0,720- \\
0,871)\end{array}$ & 8,8 & $<0.001$ & $92,31 \%$ & $70,95 \%$ & 84,2 & 71,7 & 3,2 \\
\hline HWT & $\begin{array}{l}0,781(0,655- \\
0,906)\end{array}$ & 5,7 & 0.001 & $84,62 \%$ & $73,74 \%$ & 63,2 & 79,6 & 3,2 \\
\hline FWT & $\begin{array}{l}0,852(0,793- \\
0,911)\end{array}$ & 6,2 & $<0.001$ & $92,31 \%$ & $75,42 \%$ & 65,8 & 78,6 & 3,8 \\
\hline TATWT & $\begin{array}{l}0,873(0,818- \\
0,927)\end{array}$ & 20,5 & $<0.001$ & $92,31 \%$ & $78,77 \%$ & 78,9 & 77,7 & 4,3 \\
\hline Multiparous & Multiparous & Multiparous & Multiparous & Multiparous & Multiparous & Multiparous & Multiparous & Multipe \\
\hline Cesarean & Cesarean & Cesarean & Cesarean & Cesarean & Cesarean & Cesarean & Cesarean & Cesarea \\
\hline Delivery & Delivery & Delivery & Delivery & Delivery & Delivery & Delivery & Delivery & Deliver: \\
\hline $\mathrm{RF}$ & $\begin{array}{l}\text { AUC } \\
(\% 95)\end{array}$ & Cut off & $\mathrm{p}$ & Sens & Spes & PPV & NPV & PLR \\
\hline AAWT & $\begin{array}{l}0,731(0,656- \\
0,805)\end{array}$ & 8,4 & $<0.001$ & $71,79 \%$ & $68,60 \%$ & 65,9 & 69,3 & 2,3 \\
\hline HWT & $\begin{array}{l}0,704(0,614- \\
0,795)\end{array}$ & 5,6 & $<0.001$ & $66,67 \%$ & $69,71 \%$ & 54,9 & 78 & 2,2 \\
\hline FWT & $\begin{array}{l}0,711(0,625- \\
0,798)\end{array}$ & 6,1 & $<0.001$ & $64,10 \%$ & $73,71 \%$ & 57,1 & 77 & 2,4 \\
\hline TATWT & $\begin{array}{l}0,782(0,709- \\
0,854)\end{array}$ & 19,2 & $<0.001$ & $87,18 \%$ & $69,71 \%$ & 76,9 & 69,6 & 2,9 \\
\hline
\end{tabular}

RF: Risk Factor, AUC: Area Under Curve, Sens: Sensitivity, Spes: Specifity, PPV: Positive Predictive Value, NPV: Negative Predictive Value, PLR Positive Likelihood Ratio

\section{FIGURES}

Figure-1: Anterior Abdominal Wall Thickness Measurement

Figure-2: Femur Adipose Tissue Thickness Measurement

Figure-3: Humerus Adipose Tissue Thickness Measurement 


\section{Hosted file}

Figure 1-2-3 bjog in one page.docx available at https://authorea.com/users/360037/articles/ 481767-fetal-adiposity-and-labor-dystocia-a-case-control-study 